\title{
Analýza vztahu rytmické realizace a rytmické percepce v tanečním sportu
}

\section{Analysis of the relationship rhythmic execution and rhythmic perception in dance sport}

\author{
Pavlína Vaculíková, Lenka Svobodová, Dagmar Šimberová, Kristýna Honková
}

Fakulta sportovních studií Masarykovy univerzity, Brno

\begin{abstract}
Abstrakt
Taneční sport, stejně jako ostatní sportovní odvětví patřící do oblasti esteticko-koordinačních sportů, klade vysoké nároky na úroveň takřka všech motorických schopností. Jsou to především schopnosti koordinační, které bývají limitujícím faktorem výkonu v tanečním sportu. Vzhledem ke skutečnosti, že tanec je neodmyslitelně spjat s hudbou a úzce spojen soblastí rytmických schopností, zaměrujeme se na bližší charakteristiku dvou rytmických podschopností, a to rytmické percepce a rytmické realizace. Výzkumný soubor tvořilo celkem 153 probandů ve věkovém rozpětí 17-34 let. Experimentální skupina byla složena ze 104 tanečníků (53 žen a 51 muž). Kontrolní skupinu tvořilo 49 osob - studentů gymnázia. Ke zjištění úrovně rytmické percepce jsme použili test rytmické diskriminace. Ke zjištění úrovně rytmické realizace jsme použili test nerytmického bubnování. Prokázali jsme, že taneční sport má pozitivní vliv na úroveň námi vybraných rytmických schopností. Čím déle se probandi tanci věnují, tím lepších výsledkủ dosáhli v testech. Nepodařil se nám prokázat statisticky významný vztah mezi rytmickou percepcí a realizací.
\end{abstract}

\begin{abstract}
Dance sport, like other sports belongs to the aesthetic and coordinating sports; with high demands of nearly all motoric skills. They require mainly the ability to coordinate, which is often the limiting factor of performance in dance sport. Due to the fact that dance is synonymous with music and closely associated with the rhythmic capabilities, we will focus further on detailed characteristics of the two rhythmic abilities: rhythmic perception and rhythmic execution. The research sample consisted of 153 test subjects in the age range 17-34 years. The experimental group consists of 104 dancers (53 women and 51 men). The control group consisted of 49 high school students. To examine the level of rhythmic perception, we used a test called rhythmic discrimination. To examine the level of rhythmic execution, we used a test called rhythmic drumming. We proved that dance sport has a positive effect on the level of our selected rhythmic ability, the longer the subjects danced, the better the results achieved in tests. We were unable to prove a statistically significant relationship between rhythmic perception and implementation.
\end{abstract}

Klíčová slova: $\quad$ taneční sport, koordinační schopnosti, rytmické schopnosti, rytmická realizace, rytmická percepce

Keywords: dance sport, coordination abilities, rhythmic abilities, rhythmic execution, rhythmic perception

\section{Úvod}

Koordinační schopnosti jsou nezbytnou podmínkou každé podoby pohybové činnosti a v rozhodující míře ovlivňují její efektivnost a zachování motorické jednotky. Mají široké spektrum působnosti, jak ve sportu a školní tělesné výchově, tak v běžném životě člověka. Tvoří základ pohybových a sportovních dovedností. Jsou tedy předmětem zájmu tělovýchovných pedagogů. Nové teoretické př́stupy ke studiu koordinačních schopností umožňují přehodnocení dosavadních znalostí ve větší míře než u ostatních motorických schopností. Rytmické schopnosti jako nedílná složka schopností koordinačních dovolují udržet, zapamatovat, tvořit a realizovat ohraničenou, časově-dynamickou strukturu cyklických a acyklických pohybů. Projevují se v přizpůsobení pohybů do daného vnějšího rytmu nebo přijetí vlastního 
rytmu. Udržení a vytvoření rytmu v pohybech cyklických je jednodušší než v pohybech acyklických, jejichž časově-dynamická struktura se mnohokrát opakuje, což přeje procesu rytmu pohybu (Mynarski, Raczek,1998).

Rytmus pohybu je často rozhodující schopností při vykonávání jednoduchých nebo složitých cyklických nebo acyklických pohybů. Někteří autoři považují rytmus za „pohybově ekonomický princip“. Úroveň schopnosti rytmizovat má zřejmě výrazný vliv na kvalitu a úspornost tělesných pohybů. Proto je třeba tuto schopnost neustále zdokonalovat. Vnitřní základ rytmických schopností tvoří strúíání svalového napětí a uvolnění a procesy podráždění a útlumu (Kasa, 2000).

Úroveň rytmických schopností klade mimořádné nároky na sportovce v některých disciplínách, v nichž se pohybové kompozice provádějí při hudebním doprovodu a které vyžadují nejen podřízení se rytmu hudby, ale i co možná její nejpřesvědčivější vyjádření pohybem jako je např. moderní gymnastika, krasobruslení, sportovní gymnastika nebo sportovní aerobik (Vaculíková, 2004). Do této skupiny zcela jistě patří také taneční sport.

Taneční sport řadíme do esteticko-koordinačních disciplín, ve kterých v posledních letech zaznamenáváme značný nárůst úrovně tanečníků. Posun lze vidět jak v kondiční připravenosti, tak ve fyzické i psychické odolnosti, technické vyspělosti a kompaktivnosti. Je-li technická i kondiční vybavenost párů na stejné úrovni, rozhodující roli sehrává úroveň koordinačních schopností. Většina odborných publikací o tanečním sportu se věnuje především historickému vývoji a technice standardních či latinskoamerických tanců. Naproti tomu oblast motorických schopností je velmi probádanou sférou a lze nalézat rozdílnost názorů už v jejich definicích a obecném pojmenování. Studii věnující se koordinačním schopnostem $\mathrm{v}$ souvislosti s tanečním sportem jsme nenalezli, proto se pokusíme doplnit mezeru v dosavadních poznatcích a zmapovat úroveň vybraných složek koordinačních schopností právě v tomto odvětví, ve kterém je úroveň takřka všech složek koordinačních schopností limitujícím faktorem výkonu.

\section{Sportovní tanec versus taneční sport}

Termíny „taneční sport“ a „sportovní tanec“ jsou náhradou za doposud užívaný pojem společenský tanec. Ke změnám v terminologii dochází až v souvislosti se světovým uznáním společenského tance jako sportu a jeho zařazením mezi kandidátské sporty pro olympijské disciplíny v roce 1997 (Helceletová, 2006). V literatuře se objevují oba pojmy, sportovní tanec i taneční sport. V našem př́spěvku bude používán termín taneční sport.

\section{Charakteristika tanečního sportu}

Taneční sport má jako každý jiný sport pevně stanovená pravidla, systém soutěží, hodnocení, podmínek pro postup do vyšších tříd, a je také namáhavý po fyzické i psychické stránce. Obsahuje ovšem i velkou dávku elegance, ladnosti, kultury a krásy pohybu. Není to sport agresivní, vedoucí k ničení sebe či ostatních, nesoutěží se na čas, nestřílejí se koše ani góly. Záleží jen na schopnostech tanečního páru, jeho vyspělosti a „vytancovanosti“, jak dokáže přesvědčit porotu o tom, že je ten nejlepší. Taneční sport bychom snad mohli nejlépe porovnat s krasobruslením nebo sportovní gymnastikou, kde se také sportovci vyjadřují pohybem a celkový dojem sehrává rozhodující úlohu při hodnocení (Helceletová, 2006).

Taneční sport je sportem komplexním se zaměřením na rozvoj téměř všech motorických schopností. Tanečníci musí dosáhnout vysoké úrovně jak kondičních schopností (především krátkodobé vytrvalosti), hybridních schopností (zejména rychlosti frekvence pohybu dolních končetin) nebo flexibility především v oblasti kyčelního kloubu (u partnerky při latinskoamerických tancích). Stěžejní roli hraje dosažená úroveň koordinačních schopností (rytmické schopnosti, prostorově-orientační schopnosti, rovnováhové aj.), kdy úroveň převážné většiny dílčích koordinačních schopností může sehrát významnou roli při hodnocení a umístění páru nebo formace na soutěžích. Významnou roli v rozvoji koordinačních schopností a dovedností zaujímá motorická pamět, která je limitujícím faktorem sportovního výkonu (Svobodová, Šimberová, Kopřivová, 2011).

Jak bylo zmíněno, nedílnou součástí tance je hudební doprovod a úzké propojení s oblastí rytmických schopností. Proto se dále zaměříme na bližší charakteristiku dvou rytmických podschopností, a to rytmické percepce a rytmické realizace, a jejich vzájemný vztah. 


\section{Charakteristika rytmické percepce a realizace}

Rytmická schopnost jako schopnost postihnout a vyjádřit rytmus z vnějšku daný anebo obsažený v samotné pohybové činnosti obvykle odděluje schopnost rytmické percepce od schopnosti rytmické realizace (výkonu). Někteří autoři nalezli mezi oběma schopnostmi pozitivní vztah, jiní jej popírají (Měkota, Blahuš 1983).

Schopnost rytmické percepce je definována jako schopnost vnímání akustických (často hudebních), taktilních i vizuálních $\mathrm{z}$ vnějšku přijímaných rytmů a jejich přetransformování, přenesení do pohybové činnosti (tanec, krasobruslení).

Schopnost rytmické realizace je popisována jako vystižení rytmu pohybového aktu (např. vzepření vzklopmo), „přeložení " tohoto ve vlastní představě existujícího rytmu a jeho uplatnění při vlastní pohybové činnosti. Právě schopnost rytmické realizace je nesmírně důležitá v technicko-estetických sportech, ale uplatňuje se i v jiných sportovních odvětvích, kde je nutné vhodné načasování pohybu (Lehnert, 2010).

\section{Výzkumný cíl}

Cílem našeho příspěvku je explorace úrovně dvou složek rytmických schopností, a to rytmické percepce a rytmické realizace, a především zjištění vzájemného vztahu mezi těmito složkami u osob, které se aktivně věnují tanečnímu sportu.

Podle našich předpokladů bude úroveň rytmické realizace závislá na úrovni rytmické percepce.

Pro srovnání bylo měření provedeno také u kontrolní skupiny osob, které se tanečnímu sportu ani jiné pohybové aktivitě blízké tanci aktivně nevěnují.

\section{Metody výzkumu}

Ke zjištění úrovně rytmické percepce jsme použili test rytmické diskriminace, jehož autorem je Seashore. Tento test se řadí do skupiny testů na zjištění úrovně rytmických schopností, které se soustředují na rozlišování rytmických vzorců. Použili jsme nahrávku, která byla vytvořena $\mathrm{v}$ rámci diplomové práce Jany Dohnalové (2010). Nahrávka obsahuje patnáct rytmických vzorců, po pěti k jednotlivým taktům - 2/4,3/4 a 4/4. Z celkem třiceti vzorců je patnáct vzorců shodných a patnáct vzorců rozdílných.

Do záznamového archu testované osoby zaznamenávaly zaškrtnutím „A“ pro „ano“, že rytmické vzorce jsou shodné, nebo „N“ pro „ne“ v případě, že se rytmické vzorce lišily. Zaznamenáváme počet správných odpovědí.

Ke zjištění úrovně rytmické realizace jsme použili test nerytmického bubnování. Testovaná osoba sedí u stolu, paže má na šiřku ramen, ruce položené dlaněmi dolů na stůl. Na pokyn examinátora začne provádět následující pohyby:

1. dvakrát udeří levou dlaní do stolu,

2. pravou rukou překříží levou ruku a udeří pravou dlaní dvakrát do stolu,

3. pravou dlaní se dotkne čela

4. pravou dlaní udeří do stolu vedle položené levé dlaně.

Probandi vytvořili dvojice. Navzájem si počítali počet správně provedených cyklů. Správnost počítání a zapisování byla kontrolována trenéry, případně vyučujícími. Následně se role testovaných a examinátorů vystřídaly.

Délka testu je 20 sekund. Měření se 4x opakuje. Zaznamenáváme počet správně provedených cyklů v každé sérii (Měkota, 1983).

\section{Charakteristika výzkumného souboru}

Výzkum byl proveden na počátku roku 2011. Výzkumný soubor tvořilo celkem 153 probandů ve věkovém rozpětí 17-34 let.

Experimentální skupina (dále jen ES) byla složena ze 104 tanečníků (53 žen a 51 mužů). Diagnostiku rytmických schopností jsme provedli v taneční škole, ve třech složkách s rozdílným stupněm dosažené výkonnosti (ES1, ES2, ES3). Experimentální skupina 1 (ES1) se tanečnímu sportu věnuje nejdéle, expe- 
rimentální skupina 3 (ES3) nejkratší dobu. Všechna měření jsme prováděli v rámci tréninkové jednotky, a to na začátku hlavní části.

Kontrolní skupinu (dále jen KS) tvořilo 49 osob - studentů gymnázia, kteří se nevěnují žádnému druhu tanečního sportu (46 žen, 3 muži). Měření jsme prováděli v tělocvičně a učebně v rámci hodin tělesné výchovy a př́rodovědných cvičení - v ročnících sext a septim.

\section{Zpracování}

K zaznamenání a statistickému zpracování naměřených hodnot jsme využili programu Microsoft Office Excel 2003.

Pro analýzu dat jednotlivých koordinačních schopností jsme zvolili základní statistické charakteristiky úrovně a variability souboru: aritmetický průměr, standardní chyba, medián, modus, minimální a maximální hodnoty, směrodatná odchylka, rozptyl, variační rozpětí.

K porovnání závislosti dvou koordinačních schopností rytmické percepce a rytmické realizace jsme použili koeficient korelace.

\section{Výsledky testu rytmické percepce}

Výsledky testování rytmického cítění v kompletním souboru uvádíme v tabulce 1 .

\begin{tabular}{|l|c|c|c|c|}
\hline & ES1 & ES2 & ES3 & KS \\
\hline průměr & 29,24 & 28,69 & 27,83 & 28,04 \\
\hline standardní chyba & 0,11 & 0,17 & 0,24 & 0,16 \\
\hline medián & 29 & 29 & 28 & 28 \\
\hline modus & 29 & 29 & 29 & 29 \\
\hline směrodatná odchylka & 0,73 & 0,97 & 1,29 & 1,12 \\
\hline rozptyl & 0,53 & 0,93 & 1,66 & 1,25 \\
\hline rozpětí & 3 & 4 & 4 & 4 \\
\hline minimum & 27 & 26 & 25 & 25 \\
\hline maximum & 30 & 30 & 29 & 29 \\
\hline
\end{tabular}

Tab. 1 Výsledky testu rytmické percepce

Data zkoumaného souboru jsou poměrně stejnorodá. Většina testovaných odpověděla nad 27 rytmických vzorců správně.

Nejnižší počet správně zodpovězených odpovědí je 25 a vyskytuje se pouze čtyřikrát. Maximální dosažená hodnota 30 správných odpovědí se objevuje dokonce u 21 testovaných.

U skupiny KS se nejčastěji pohyboval počet správně určených rytmických vzorců od 28 odpovědí výš.

U skupiny ES3 je překvapivě aritmetický průměr nižší, než u KS (nevěnující se tanci), ale hodnoty mediánu i modusu jsou stejné - rytmická percepce je zhruba na stejné úrovni.

Ve skupině ES2 již dochází k navýšení všech počítaných průměrů, nejčastější hodnota se pohybuje kolem 29 správných odpovědí. Nejnižší počet správných odpovědí je 26 a vyskytuje se jen jednou.

Skupina ES1 dosáhla nejvyšší hodnoty aritmetického průměru, hodnoty mediánu a modusu jsou však shodné s ES2. Nejčastěji se vyskytoval počet správných odpovědí 29 a 30, žádná testovaná osoba nezískala méně než 27 správných odpovědí.

\section{Interpretace výsledků testu rytmické percepce}

Testované osoby všech skupin respektovaly nutnost klidného prostředí v průběhu testu, $\mathrm{v}$ žádné skupině nedošlo k narušení poslechu nahrávky. Někteří probandi ze skupin KS a ES3 si po skončení posle- 
chu stěžovali na časovou náročnost testu. Se vzrůstající časovou náročností klesala schopnost soustředění testovaných osob. Tento fakt může být dán nižším průměrným věkem respondentů, ale podle našeho názoru především skutečností, že skupiny ES1 a ES2 mají dlouholeté taneční zkušenosti, probandi těchto skupin jsou zvyklí se po danou dobu intenzivně soustředit právě na poslech hudby, resp. rytmických impulsů.

Z výsledků je patrné, že jeden rytmický vzorec dělal probandům větší problémy - v záznamovém archu lze vyčíst, že jde v drtivé většině o jeden a týž rytmický vzorec. Protože se tento problém vyskytuje ve všech testovaných skupinách, nejedná se zřejmě o rušivý vnější vliv (náhlý hluk, vyrušení příchodem osoby), ale skutečně jde o hůře vnímanou rytmizaci (jde o rytmický vzorec č. 10 - poslední v prvním bloku). Další chyby v odpovědích jsou už nahodilé.

Vzhledem k tomu, že výsledky testu rytmické percepce nevykazují normální rozdělení dat, naopak rozdělení je vskutku zvláštní, můžeme pomýšlet na chybu testu. Osobně se domníváme, že test je příliš jednoduchý, nahrávka postrádá složitější rytmy - např. „tečkovaný“ rytmus, synkopy, delší rytmické vzorce.

Pokud se i přesto pokusíme o závěry, zdá se, že taneční vyspělost má skutečně na rytmickou percepci vliv. U skupiny tanečníků s nejdelší taneční zkušeností (ES1, ES2) jsou výsledky testu rytmické percepce na vyšší úrovni, než u skupiny netančících (KS) či tanečních začátečníků (ES3). Otázkou zůstává, zda lepší tanečníci mají lepší rytmickou percepci proto, že déle tancují, nebo se stali lepšími tanečníky proto, že lépe slyší rytmus.

\section{Výsledky testu rytmické realizace}

V tabulce 2 uvádíme výsledky testů rytmického vyjádření v kompletním souboru.

\begin{tabular}{|l|c|c|c|c|}
\hline & ES1 & ES2 & ES3 & KS \\
\hline průměr & 55,6 & 44,59 & 49,2 & 51,49 \\
\hline standardní chyba & 0,5 & 0,87 & 2,12 & 1,47 \\
\hline medián & 55,5 & 45 & 50 & 50 \\
\hline modus & 57 & 49 & 53 & 50 \\
\hline směrodatná odchylka & 3,22 & 4,9 & 11,59 & 10,31 \\
\hline rozptyl & 10,39 & 23,99 & 134,23 & 106,21 \\
\hline rozpětí & 14 & 18 & 62 & 41 \\
\hline minimum & 49 & 35 & 10 & 33 \\
\hline maximum & 63 & 53 & 72 & 74 \\
\hline
\end{tabular}

Tab. 2 Výsledky testu rytmické realizace

Data zkoumaného souboru jsou dosti nestejnorodá. Rozptyl počtu ukončených cyklů se pohybuje od 10 do 74 s tím, že průměr celé skupiny je kolem 50 .

U skupiny KS jsme zaznamenali nejčetnější zastoupení kolem 54 cyklů, což je pěkný výsledek. I když část probandů test prováděla $\mathrm{v}$ učebně u stolů, část $\mathrm{v}$ tělocvičně na zemi, nepozorovali jsme žádné výrazné rozdíly ve výsledcích.

Skupina ES3 se v testu rytmické realizace jeví jako slabší. Vyskytuje se tu hodnota minima kompletního souboru, což je 10 ukončených cyklů, a také ostatní hodnoty jsou na nižší úrovni než u zbývajících souborů.

Skupina ES2 je jako celek v testu rytmické realizace nejslabší. Nevyskytují se sice extrémně nízké hodnoty, ale její maximum 53 ukončených cyklů je shodné s průměrným výsledkem ostatních skupin. 
Skupina ES1 je v úrovni rytmické realizace nejlépe. Nejhorším výsledkem je 49 dokončených cyklů. A přestože žádná testovaná osoba nepřekročila 63 cyklů, většina respondentů této skupiny se umístila v lepší polovině rozpětí výsledků.

\section{Interpretace výsledků testu rytmické realizace}

Testování úrovně rytmické realizace probíhalo ve čtyřech dvacetisekundových intervalech, výsledky testu byly součtem všech pokusů. Testované osoby tedy měly možnost si v následujících pokusech zlepšit dosažené skóre, nicméně tato zlepšení jsme zaznamenali jen ojediněle. Často byl zřejmý nárůst mezi 1. a 2. pokusem a následný propad ve 3. a 4. měření. Dalším obvyklým vzorcem výsledků byl vyrovnaný průběh dosažených výsledků ve všech čtyřech pokusech.

Ze statistického hlediska není rozdělení dat normální, což ale v tomto případě nebude chybou testu, jako spíše motivací probandů.

U kontrolního souboru netančících (KS) jsme pozorovali větší nadšení a zapálení pro věc, byli motivovaní překonáváním výsledků spolužáků, zatímco experimentální skupiny tanečníků často prováděly první i druhý pokus naplno, a u dalších dvou polevovaly, „nebavilo“ je to. Nejvýraznější projevy nevole jsme sledovali ve skupině ES2, a není tedy asi náhodou, že se tato skupina umístila nejhůře. To, že skupina ES3 dosáhla zdaleka nejhoršího výsledku, může být dáno i tím, že průpravná část tréninkové jednotky, po které bylo měření provedeno, byla velmi fyzicky náročná.

Výsledky testované rytmické realizace, tedy schopnosti pohybového vyjádření rytmu, jsou u kontrolní skupiny netančících (KS) na stejné úrovni jako u tanečníků začínajících (ES3). Propad ve skupině ES2 si vysvětlujeme zřejmým odbytím testu. Nejvyspělejší tanečníci (ES1) dosahují prokazatelně lepších výsledků.

\section{Analýza vztahu rytmické realizace a rytmické percepce}

Předpokládali jsme, že čím je vyšší úroveň tanečních dovedností, tím bude těsnější vztah mezi rytmickou realizací a rytmickou percepcí. Mezi úrovní rytmické realizace a rytmické percepce jsme předpokládali statistickou závislost.

Pro srovnání kvantitativních znaků jsme použili výpočet korelační analýzy. Hodnoty výsledků jsou uvedeny v tabulce 3 .

\begin{tabular}{|l|c|c|c|c|c|c|c|c|}
\hline & ES1 & ES1 & ES2 & ES2 & ES3 & ES3 & KS & KS \\
\hline & percepce & realizace & percepce & realizace & percepce & realizace & percepce & realizace \\
\hline průměr & 55,6 & 29,24 & 44,59 & 28,69 & 49,2 & 27,83 & 51,49 & 28,04 \\
\hline $\begin{array}{l}\text { standardní } \\
\text { chyba }\end{array}$ & 0,5 & 0,11 & 0,88 & 0,17 & 2,12 & 0,24 & 1,47 & 0,16 \\
\hline medián & 55,5 & 29 & 45 & 29 & 50 & 28 & 50 & 28 \\
\hline modus & 57 & 29 & 49 & 29 & 53 & 29 & 50 & 29 \\
\hline $\begin{array}{l}\text { směrodatná } \\
\text { odchylka }\end{array}$ & 3,22 & 0,73 & 4,9 & 0,97 & 11,59 & 1,29 & 10,31 & 1,12 \\
\hline rozptyl & 10,39 & 0,53 & 23,99 & 0,93 & 134,23 & 1,66 & 106,21 & 1,25 \\
\hline rozpětí & 14 & 3 & 18 & 4 & 62 & 4 & 41 & 4 \\
\hline minimum & 49 & 27 & 35 & 26 & 10 & 25 & 33 & 25 \\
\hline maximum & 63 & 30 & 53 & 30 & 72 & 29 & 74 & 29 \\
\hline $\begin{array}{l}\text { koeficient } \\
\text { korelace }\end{array}$ & \multicolumn{2}{|c|}{0,5} & 0,14 & & 0,04 & & 0,06 \\
\hline
\end{tabular}

Tab. 3 Analýza vztahu rytmické realizace a rytmické percepce 
U kontrolní skupiny KS je z vypočítaných hodnot patrné, že se zde neformuje žádná lineární závislost, čemuž odpovídá i hodnota koeficientu korelace 0,06 .

Koeficient korelace u skupiny ES3 je 0,04, tedy ještě nižší než u skupiny netančících (KS), a žádnou souvislost mezi rytmickou percepcí a realizací neindikuje.

V souboru ES2 je koeficient korelace 0,14, což je sice více než u předchozích skupin, ale stále to neznačí žádnou lineární závislost.

Ve skupině ES1 docházejí vypočítané hodnoty korelačního koeficientu 0,5 ke statisticky významné závislosti, ale rozložení výsledků testu rytmické percepce výsledek značně zkresluje.

\section{Interpretace srovnání výsledků testu rytmické percepce a realizace}

Výsledky testu rytmické percepce mají tendenci diskrétních bodů a nikoli spojitého rozložení. Je to proto, že pro většinu probandů byl test rytmické diskriminace od Seashorea př́liš snadný, a hodnoty výsledků se tak pohybovaly v úzkém rozpětí.

Korelační koeficienty se pohybují na tak nízkých hodnotách, že můžeme tvrdit, že rytmická percepce a realizace na sobě nejsou lineárně závislé. Kdybychom ale použili jiný test rytmické percepce, možná by se výsledky mohly diametrálně lišit.

\section{Závěr}

V naší práci jsme se zaměřili na sledování vztahu mezi dílčímí složkami rytmických schopností. Do projektu jsme zařadili dvě složky, a to rytmickou percepci a rytmickou realizaci. Pokusili jsme se mezi nimi identifikovat vzájemné závislosti. Identifikace možných vztahů mezi jednotlivými dílčími schopnostmi je významná z toho důvodu, že rozvoj jedné dílčí schopnosti může mít pozitivní vliv na rozvoj jiné. Tento vztah se nám však nepodařilo prokázat.

Na základě získaných výsledků jsme došli k závěru, že taneční sport má pozitivní vliv na úroveň testovaných koordinačních schopností: rytmickou percepci i realizaci. Čím déle se probandi tanci věnují, tím lepší jsou jejich výsledky v testech.

\section{Literatura}

DOHNALOVÁ, J. Komparace rytmické percepce a rytmické realizace. Diplomová práce, Brno: FSpS MU, 2010.

HELCELETOVÁ, K. Regenerace ve standardních tancích. Bakalářská práce. Brno: FSPS MU, 2006.

HONKOVÁ, K. Zjištování koordinačních schopností v tanečním sportu. Diplomová práce. Brno: FSPS MU, 2011.

KASA, J. Športová antropomotorika. Bratislava. 2000, s. 207. ISBN: 80-968252-3-2

MĚKOTA, K., BLAHUŠ, P. Motorické testy v tělesné výchově. Praha: SPN 1983. Kapitola 3, Testování motorických schopností a dovedností, s. 97-253.

LEHNERT, M. Koordinační schopnosti. [online]. 2010 [cit. 2010-12-15]. Univerzita Palackého v Olomouci. Dostupné z WWW: <www.upol.cz/fileadmin/user_upload/FTK-dokumenty/CTS/ Lehnert koordinac_ treneri.ppt

MYNARSKI, W., RACZEK, J., LJACH,W. Teoretyczno-empiryczne podstawy ksztattowania i diagnozowania koordynacyjnych zdolnośći motorycznych. In: Studia nad Motorycznośćia Ludzka, nr. 4, Katowice: AWF, 1998. ISSN 1230-4646, s. 187.

SVOBODOVÁ, L.; ŠIMBEROVÁ, D.; KOPǨIVOVÁ, J. Tanec jako faktor ovlivñující rovnováhové schopnosti jedince $v$ období senia. In Pohyb a zdraví. Trenčín, 2011, ISBN 978-80-8075-487-7

VACULÍKOVÁ, P. Vliv tréninku aerobiku na rozvoj motorických schopností u dětí ve věku 10-14 let. Disertační práce. Brno: FSPS MU, 2004. 